\title{
Toxigenic potential of Aspergillus flavus tested in different culture conditions
}

\author{
Potencial toxigênico de Aspergillus flavus testado em diferentes meios e condições
}

\author{
Ana Carolina RITTER ${ }^{1}$, Michele HOELTZ ${ }^{1}$, Isa Beatriz NOLL ${ }^{1 \star}$
}

\begin{abstract}
The objective of the present work was to evaluate the capacity of three isolates of Aspergillus flavus to produce aflatoxin under different culture conditions. This experiment was based on a $2^{3}$ factorial design, in which the independent variables were temperature $\left(20-40{ }^{\circ} \mathrm{C}\right)$, incubation time (7-21 days), and the $\mathrm{pH}$ (2.0-6.0) in two different synthetic media. The optimal conditions were applied to non-aflatoxigenic isolates previously tested in coconut agar. Aflatoxin $\mathrm{B}_{1}$ was extracted directly from the synthetic cultures with chloroform. Thin Layer Chromatography (TLC) and Photographic Photometry were utilized to identify and quantify the compounds. Preliminary results showed that YES agar was an alternative medium for detecting the toxigenic potential of Aspergillus flavus in the following conditions: $\mathrm{pH}$ of 5.2 , temperature of $25^{\circ} \mathrm{C}$, and incubation time of 11 days producing $206.05 \mathrm{ng}$. $\mathrm{CFU}^{-1}$ of aflatoxin $\mathrm{B}_{1}$. Of the 30 non-aflatoxigenic isolates, 12 presented a positive result in the optimal media and conditions tested.
\end{abstract}

Keywords: Aspergillus flavus; aflatoxin-producing; incubation time; temperature; $p H$; culture media.

\section{Resumo}

O objetivo do presente trabalho foi avaliar a capacidade produtora de aflatoxina de três isolados de Aspergillus flavus sob diferentes condições de crescimento. $\mathrm{O}$ experimento foi baseado num delineamento experimental $2^{3}$, tendo como variáveis independentes a temperatura $\left(20-40{ }^{\circ} \mathrm{C}\right)$, tempo de incubação (7-21 dias) e pH (2,0 e 6,0) em dois meios de cultura diferentes. As melhores condições encontradas foram empregadas com isolados não toxigênicos testados previamente em Agar Coco. A aflatoxina $\mathrm{B}_{1}$ foi extraída com clorofórmio, diretamente dos meios sintéticos. A identificação e a quantificação do composto foram efetuadas por Cromatografia em Camada Delgada e Fotometria Fotográfica. Como resultados preliminares, o meio de cultura YES se mostrou como uma alternativa para detectar o potencial toxigênico de Aspergillus flavus, nas seguintes condições: pH 5,2, temperatura de $25^{\circ} \mathrm{C}$ e tempo de incubação de 11 dias, com uma produção de 206,05 ng.UFC ${ }^{-1}$ de aflatoxina $\mathrm{B}_{1}$. Dos 30 isolados não toxigênicos, 12 apresentaram resultado positivo nas condições e meios de cultura testados.

Palavras-chave: Aspergillus flavus; aflatoxina; tempo de incubação; temperatura; $p H$; meios de cultura.

\section{Introduction}

Mycotoxins are secondary metabolites that are produced by certain filamentous fungi (SWEENEY; DOBSON, 1998; D’MELLO; MACDONALD, 2002; GIRAY et al., 2007). More than 20 species of Aspergillus produce mycotoxins; however, the most easily found are those from the flavi section, which includes three species: A. flavus, A. parasiticus and A. nomius (FRISVAD et al., 2006; IQBAL et al., 2006).

The four aflatoxins that are produced naturally are $B_{1}, B_{2}, G_{1}$, and $\mathrm{G}_{2} ; \mathrm{B}_{1}$ is the most commonly found in high concentrations in food and feed (SWEENEY; DOBSON, 1998; VAAMONDE et al., 2003). However, not all strains of A. flavus produce aflatoxins; since several strains are non-toxigenic aflatoxin, tsynthesis may become unstable in this species (ORDAZ et al., 2003).

Aflatoxins are compounds with a hepatotoxic, carcinogenic, and teratogenic potential that can affect either humans or animals (MOSS, 2002; SALEEMULLAH et al., 2006; D'MELLO; MACDONALD, 2002). According to an IARC estimates (INTERNATIONAL..., 2002), aflatoxins can be considered carcinogenic to humans (group I).
The conditions that promote mycotoxin production are usually more restricted than those for mould growth (GUITAKOU et al., 2006; BRESLER et al., 1995). Mycotoxin production depends on fungal species, substrate, temperature of the media, $\mathrm{pH}$, relative humidity, and storage or incubation time (BRAGULAT et al., 2001; FILTENBORG et al., 1983; SMEDSGAARD, 1997; BELLI et al., 2004; WEELER et al., 1991).

According to Park and Bullermann (1983), substrate is one of the most important factors controlling the production of secondary metabolites. In addition, the optimal medium for production of secondary metabolites by fungi depends on the metabolite, species, and isolate (BRAGULAT et al., 2001; MEDINA et al., 2006). For example, different strains of $A$. flavus have been shown to produce aflatoxins at different rates when cultured under similar conditions (HUSSEIN; BRASEL, 2001; FILTENBORG et al., 1996).

Some specially developed media can identify toxigenic strains of Aspergillus, such as Aspergillus flavus and parasiticus agar (AFPA) (PITT et al., 1983). Another approach to the

Received 26/11/2009

Accepted 9/7/2010 (004263)

${ }^{1}$ Instituto de Ciência e Tecnologia de Alimentos - ICTA, Universidade Federal do Rio Grande do Sul - UFRGS, Av. Bento Gonçalves, 9500, prédio 43212, Campus do Vale, Agronomia, Porto Alegre, RS, Brazil, e-mail: isabnoll@adufrgs.ufrgs.br

${ }^{*}$ Corresponding author 
characterization of strains of $A$. flavus and A. parasiticus, both aflatoxin producers, was developed by Lin and Dianese (1976). Although it is a simple and useful technique, some false negative results may be detected (TANIWAKI, 1996).

Considering the importance of evaluating alternative and efficient methods for the characterization of toxigenic potential, the objectives of this study were to evaluate the growth capacity and toxigenic potential of three Aspergillus flavus strains isolated from rice (Oryza sativa L.) in different culture conditions.

\section{Materials and methods}

\subsection{Fungal isolation and identification}

All fungi tested in this study were isolated from rice (Oryza sativa L.) and identified according to Klich and Pitt (1988) by Hoeltz (2005) during the years 2003 and 2004. A total of 33 strains of A. flavus were used in the experiment. According to the method developed by Lin and Dianese (1976), three proved to be aflatoxigenic. Those three isolates were classified as A. flavus A43, A46, and A21.

\subsection{Culture media}

The following culture media were used in the present work: YES: $20 \mathrm{~g}$ yeast extract, $150 \mathrm{~g}$ saccharose, $20 \mathrm{~g}$ agar, $0.5 \mathrm{~g}$ magnesium sulphate, and $100 \mathrm{~mL}$ distilled water; CYA: 5.0 g yeast extract, $30.0 \mathrm{~g}$ saccharose, $15.0 \mathrm{~g}$ agar, $10.0 \mathrm{~mL}$ concentrated Czapeck, $1.0 \mathrm{~g} \mathrm{H}_{2} \mathrm{HPO}_{4}$, and $100 \mathrm{~mL}$ distilled water; coconut agar: $600 \mathrm{~mL}$ coconut milk, $200 \mathrm{~mL}$ distilled water, and $16 \mathrm{~g}$ agar. The $\mathrm{pH}$ of the media was adjusted to 2.0 , $2.8,4.0,5.2$, and 6.0 using $10 \%$ tartaric acid. The media were autoclaved at $121^{\circ} \mathrm{C}$ for 15 minutes and poured into $90 \mathrm{~mm}$ Petri dishes, which held approximately $15 \mathrm{~mL}$ of media.

\subsection{Culture conditions}

Fungi were grown in Sabouraud agar (Merck) for 7 days at $25^{\circ} \mathrm{C}$ to obtain heavy sporulation. Spore suspensions were obtained by harvesting spores of each isolate and suspending them in sterile distilled water containing $0.005 \%$ of a wetting agent (Tween 80). CYA and YES agar plates were needleinoculated centrally with each spore suspension and finally incubated at the required temperature $\left(20,25,30,35\right.$, and $\left.40^{\circ} \mathrm{C}\right)$ for 7-21 days.

\subsection{Qualitative analysis of aflatoxin B1}

After the appropriate incubation times, the mycelium of each fungal colony was scraped off the Petri dish, cut into strips, and homogenized with approximately $5 \mathrm{~mL}$ of chloroform (FITELBORG et al., 1983, with modifications). The extracts were applied to plates of silica gel 60G (Merck) using capillaries and were eluted with toluene, chloroform, ethyl acetate, and formic acid (35:25:25:10). After developing the chromatogram, the plates were viewed under long-wavelength ultraviolet light $(365 \mathrm{~nm})$ to detect the characteristic fluorescence of aflatoxin B1 (LIN; DIANESE, 1976).

\subsection{Quantification of aflatoxin B1}

The samples to be quantified were applied to the plates with $25,20,15$, and $10 \mathrm{ng}$ pattern of aflatoxin B1 and 80,60, 40 and $20 \mu \mathrm{L}$ of each sample. The chromatographic plates were eluted with chloroform-acetone (90:10) (BRASIL, 2005). The fluorescent spots visualized under UV light were analysed using an Olympus photometric camera with a 5.1 megapixel CCD detector. Ten photographs of each sample were taken; five with the left standard and five with the right standard. Spots and fluorescence intensity were measured using the software IMSTAT (image statistics) from the IRAF (Image Reduction Astronomical Facility) package following the standard procedures used in Astronomy to measure source brightness (LANCASTER et al., 2005). IMSTAT allows the plate background to be discounted by measuring the surrounding area of each spot to obtain the intrinsic brightness of the spots. In all cases, the standard curve was fitted by linear regression with a correlation coefficient higher than 0.95 . The ten values of each sample fluorescent $\mathrm{AFB}_{1}$ spot intensity were promediated and interpolated in the standard curve.

The detection limit was tested by the application of 2, 4, 6 and $8 \mu \mathrm{L}$ of aflatoxin $\mathrm{B}_{1}$ standard solution corresponding to 1 , 2,3 and 4 ng aflatoxin.

\subsection{Determination of the aflatoxin-producing ability of non-aflatoxigenic isolates}

Thirty non-aflatoxigenic isolates previously tested in coconut agar (LIN; DIANESE, 1976) were tested using the optimal conditions determined above, on both media (CYA and YES). The identity of aflatoxin $B_{1}$ was confirmed using the method of Przybylski (1975), and the aflatoxigenic potential was tested again on coconut agar medium.

\subsection{Statistical analysis}

In order to carry out this experiment, a central composite planning constituted of a factorial $2^{3}$ with three central points and six axial points resulting in 17 experiments (RODRIGUES, 2005). The central composite design was used to study the effect of temperature, $\mathrm{pH}$, incubation time, and their interaction. The culture media were analyzed by response surface methodology using Statistica 7.0 (Statsoft, USA) software resulting in three Pareto graphics.

\section{Results and discussion}

\subsection{Interaction of independent variables ( $p H$, temperature, and incubation time)}

The three isolates A43, A46, and A21 tested in this work were aflatoxigenic in different conditions, as shown in Table 1. In some cases, two isolates presented the same behaviour and produced aflatoxin $\mathrm{B}_{1}$ in the same conditions of $\mathrm{pH}$, time, temperature, and culture media (CYA and YES).

The isolates $\mathrm{A} 43$ and $\mathrm{A} 21$ produced aflatoxin $\mathrm{B}_{1}$ in the two following conditions: at $20^{\circ} \mathrm{C}$ with a $\mathrm{pH}$ of 4.0 and incubation time of 14 days, and at $25^{\circ} \mathrm{C}$ with a pH of 5.2 and an incubation 
Table 1. Independent Variables Interaction (pH, temperature, and incubation time) and quantification analyses.

\begin{tabular}{|c|c|c|c|c|c|c|c|c|c|}
\hline & \multirow[t]{2}{*}{${ }^{\circ} \mathrm{C}$} & \multirow[t]{2}{*}{$\mathrm{pH}$} & \multirow[t]{2}{*}{ Time (days) } & \multirow{2}{*}{$\begin{array}{c}\text { A43 } \\
\text { Quant. (ng) }\end{array}$} & \multirow{2}{*}{$\begin{array}{c}\text { YES A46 } \\
\text { Quant. (ng) }\end{array}$} & \multirow{2}{*}{$\begin{array}{c}\text { A21 } \\
\text { Quant. (ng) }\end{array}$} & \multirow{2}{*}{$\begin{array}{c}\text { A43 } \\
\text { Quant. (ng) }\end{array}$} & \multirow{2}{*}{$\begin{array}{c}\text { CYA A46 } \\
\text { Quant. (ng) }\end{array}$} & \multirow{2}{*}{$\begin{array}{c}\text { A21 } \\
\text { Quant. (ng) }\end{array}$} \\
\hline & & & & & & & & & \\
\hline 1 & 25 & 2,8 & 11 & - & - & - & - & - & - \\
\hline 2 & 35 & 2,8 & 11 & - & - & - & - & - & - \\
\hline 3 & 25 & 5,2 & 11 & 206,05 & - & - & 35,2 & - & - \\
\hline 4 & 35 & 5,2 & 11 & - & - & - & - & - & - \\
\hline 5 & 25 & 2,8 & 18 & - & - & - & - & - & - \\
\hline 8 & 35 & 5,2 & 18 & - & - & - & - & - & - \\
\hline 9 & 30 & 4 & 14 & - & - & - & - & - & - \\
\hline 10 & 30 & 4 & 14 & - & - & - & - & - & - \\
\hline 11 & 30 & 4 & 14 & - & - & - & - & - & - \\
\hline 12 & 20 & 4 & 14 & 18,85 & 17,0 & 40,1 & 42,4 & - & 52,58 \\
\hline 16 & 30 & 4 & 7 & - & - & - & - & - & - \\
\hline 17 & 30 & 4 & 21 & - & - & - & - & - & - \\
\hline
\end{tabular}

time of 18 days. Only one isolate, A46, did not show any signs of toxicity in the combinations of the conditions analysed when grown on CYA medium. This isolate also produced aflatoxin $\mathrm{B}_{1}$ in the smallest number of combinations.

With regard to the different temperature values tested (20, $25,30,35$ and $40^{\circ} \mathrm{C}$ ), only 20 and $25^{\circ} \mathrm{C}$ proved to be appropriate for aflatoxin $\mathrm{B}_{1}$ production.

These results conflict with those of Gqaleni et al. (1997), who reported that the optimal temperature for the production of aflatoxin was $30^{\circ} \mathrm{C}$ using the CYA and YES media.

The production of aflatoxin $\mathrm{B}_{1}$ occurred only at $\mathrm{pH} 4.0$ and 5.2 , and $\mathrm{pH} 5.2$ appeared most frequently in the combinations in which the isolates were aflatoxin $\mathrm{B}_{1}$-producers. Molina and Giamuzzi (2002) studied the effect of pH (5.5 and 5.9) on the production of aflatoxin $\mathrm{B}_{1}$, and reported that $\mathrm{pH} 5.9$ gave the highest aflatoxin levels.

The minimum period of incubation necessary for the production of aflatoxin $B_{1}$ was eleven days. However, fourteen and 18 days were the periods of time during which the production reached the highest number of combinations. Frisvad and Filtenborg (1983) analysed Aspergillus cultures in CYA and YES media for a period of 7, 9, 12, and 14 days of incubation, and concluded that 14 days was the optimal length of time for mycotoxin development.

Gqaleni et al. (1996) and Leontopoulos et al. (2003) reported that aflatoxin production was observed after the third day of incubation on YES medium. A year later, Gqaleni et al. (1997) reported that aflatoxins were observed after 5 days incubation of an Aspergillus flavus isolate on CYA and YES media, and that aflatoxin production reached the maximum rate at the end of 15 days incubation. Park and Bullerman (1983) inoculated spores of $A$. flavus and A. parasiticus in cheese and rice and analysed the production of aflatoxin $B_{1}$ over the following periods: $7,10,14,21$, and 28 days. They concluded that aflatoxin production reached the maximum rate at 14 days.

\subsection{The effects of culture media on aflatoxin $B_{1}$ production}

\section{Qualitative analysis}

The three tested isolates differed when inoculated under the same conditions on different media. The A43 isolate, on CYA and YES, produced aflatoxin $\mathrm{B}_{1}$ at $25^{\circ} \mathrm{C}, \mathrm{pH} 5.2$, and 11 days incubation time. The A46 isolate produced aflatoxin $\mathrm{B}_{1}$ only on YES medium $\left(20^{\circ} \mathrm{C}, \mathrm{pH} 4.0\right.$, and 14 days). These data suggest an advantage of the YES medium when compared to the CYA medium.

Abranson and Clear (1996) tested both media for mycotoxin production and reported that CYA agar was slightly better than YES agar. This may be due to the amount of saccharose in the media (15\% in YES and 3\% in CYA); this can lead to a less hydrophilic and more permeable layer for lipophilic solvents allowing better extraction of the secondary metabolites from the CYA medium.

Bragulat et al. (2001) and Frisvad and Filtenborg (1983) reported that the CYA and YES media should be used together for the detection of toxigenic potential in fungi since they seemed to allow the production of different mycotoxins.

\section{Quantitative analysis}

To quantify the production of aflatoxin $B_{1}$ by the three tested isolates, the same conditions and experimental design were used but only with the combinations of conditions in which the isolates produced toxins. The experiments were replicated twice and the averages were analysed statistically (Table 1) using the software Statistica 7.0. 
The isolate A43 inoculated in YES medium at pH 5.2, $25^{\circ} \mathrm{C}$ and with an incubation time of 11 days produced the highest levels of aflatoxin B1 (206.05 ng.CFU ${ }^{-1}$ ). When inoculated in CYA medium, this same isolate produced much lower levels (35.2 ng.CFU ${ }^{-1}$ ) under the same conditions Gqaleni et al. (1997) reported the production of $0.226 \mu \mathrm{g} \cdot \mathrm{mL}^{-1}$ in YES medium at an $\mathrm{a}_{\mathrm{w}}$ of 0.95 and $0.183 \mu \mathrm{g} \cdot \mathrm{mL}^{-1}$ in CYA medium. It should be noted that the combinations of the conditions analysed in this study differed from those used by Gqaleni, who did not consider the $\mathrm{pH}$ in the media, but did consider their water activity.

On the YES medium, an incubation time of 11 days promoted the highest production of aflatoxin $\mathrm{B}_{1}\left(206.05 \mathrm{ng}^{\mathrm{C}} \mathrm{CFU}{ }^{-1}\right)$; on the CYA medium, the best results were produced after 18 days of incubation (178 ng.CFU ${ }^{-1}$ ), when the A21 isolate was incubated at a $\mathrm{pH}$ of 5.2 and a temperature of $25^{\circ} \mathrm{C}$.

After 14 days of incubation on YES medium, the concentration of aflatoxin was slightly lower compared with the two other periods (11 and 18 days). These results differ from those found by Gqaleni et al. (1996), who concluded that the aflatoxin detected on the YES medium was produced from the second day of incubation and reached its highest concentration (130 $\left.\mu \mathrm{g} \cdot \mathrm{g}^{-1}\right)$ after 15 days; the concentration subsequently decreased to $75 \mu \mathrm{g} \cdot \mathrm{g}^{-1}$ after 21 days.

The production of aflatoxin B1 by isolate A21 on the YES medium was positively influenced by $\mathrm{pH}(\mathrm{p}=0.1)$. This means that as the $\mathrm{pH}$ increased the production of the mycotoxin increased (Figure 1).

When analysed individually, the $\mathrm{pH}$ effect was significantly negative and the temperature was significantly positive for the isolates A43 and A21, when inoculated on CYA (Figure 2 and 3). This means that if the $\mathrm{pH}$ is reduced and the incubation time is increased, the production of aflatoxin $B_{1}$ may be higher.

On the CYA medium, the production capacity of the same strain was influenced by the interaction of all factors tested when analysed together $(\mathrm{p}=0.5)$ (Figure 3$)$.

\subsection{Aflatoxin-producing ability}

Thirty isolates thought to be non-aflatoxin producers (HOELTZ, 2005) were tested on coconut agar in the optimal conditions determined in this study. Of these, 12 produced aflatoxin $\mathrm{B}_{1}$ (Table 2).

We found that ten isolates $(1,3,4,5,7,9,12,8,10$ and 11) proved to be producers in the same conditions $\left(20^{\circ} \mathrm{C}, \mathrm{pH} 4.0\right.$, and 14 days of incubation); three in CYA $(8,10$ and 11) and four in YES media $(5,7,9$, and 12$)$. Three isolates (1, 3 and 4$)$ were producers at $20^{\circ} \mathrm{C}, \mathrm{pH} 4.0$, and 14 days of incubation, on both media. Two isolates (2 and 6) were producers at $25^{\circ} \mathrm{C}, \mathrm{pH} 5.2$, and 18 days of incubation, both on CYA and YES media. Isolate 2 also produced aflatoxin $\mathrm{B}_{1}$ at $25^{\circ} \mathrm{C}, \mathrm{pH} 5.2$, and 11 days of incubation on the YES medium.

Interestingly, the aflatoxin-producing isolates at $\mathrm{pH} 4.0$ and $20^{\circ} \mathrm{C}$ appeared to be non-producing isolates at $\mathrm{pH} 5.2$ and $25^{\circ} \mathrm{C}$. This reveals an advantage of the YES medium because more isolates produced aflatoxin $B_{1}$ when inoculated on this medium under a large range of conditions $\left(25^{\circ} \mathrm{C}, \mathrm{pH} 5.2\right.$, 11 days; $25^{\circ} \mathrm{C}, \mathrm{pH} 5.2,18$ days; and $20^{\circ} \mathrm{C}, \mathrm{pH} 4.0$, and 14 days). Leontopoulos et al. (2003) concluded that YES agar is a great

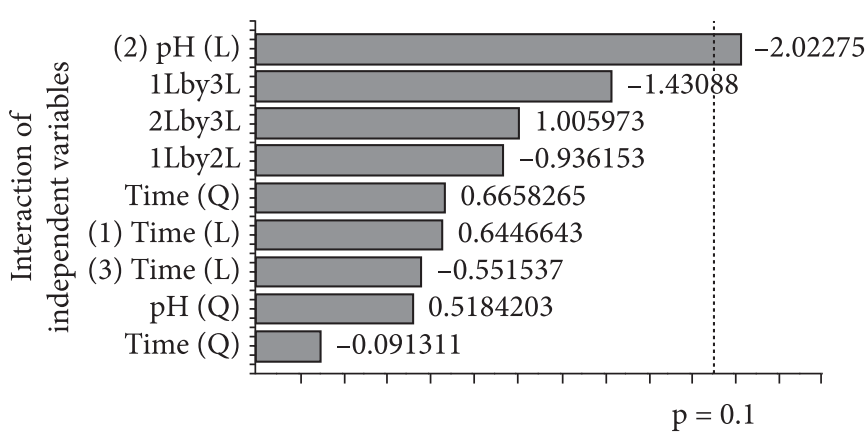

Standardized effect estimate (absolute value)

Figure 1. Pareto graphic showing the positive influence $(\mathrm{p}=0.1)$ of the $\mathrm{pH}$ on aflatoxin $\mathrm{B} 1$ production by isolate $\mathrm{A} 21$ in the YES medium, where 1 represents the temperature, 2 represents the $\mathrm{pH}$, and 3 represents the incubation time.

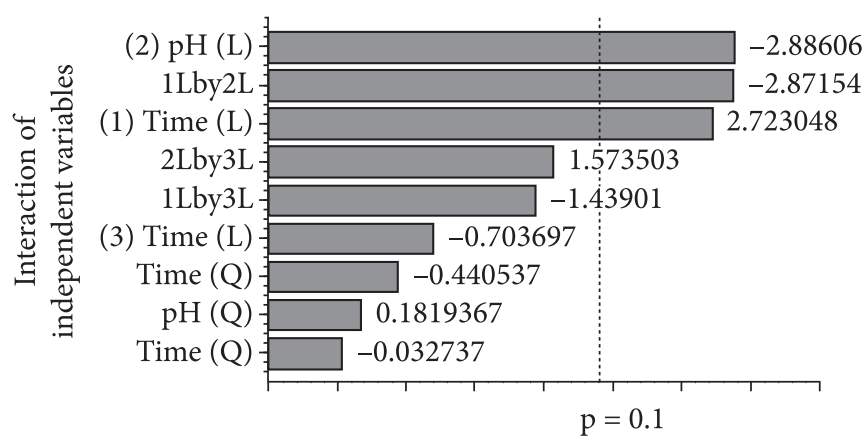

Standardized effect estimate (absolute value)

Figure 2. Pareto graphic showing the negative influence of $\mathrm{pH}$ and positive influence of temperature $(\mathrm{p}=0.5)$ on aflatoxin $\mathrm{B} 1$ production by isolate $\mathrm{A} 43$ in the CYA medium, where 1 represents the temperature, 2 represents the $\mathrm{pH}$, and 3 represents the incubation time.

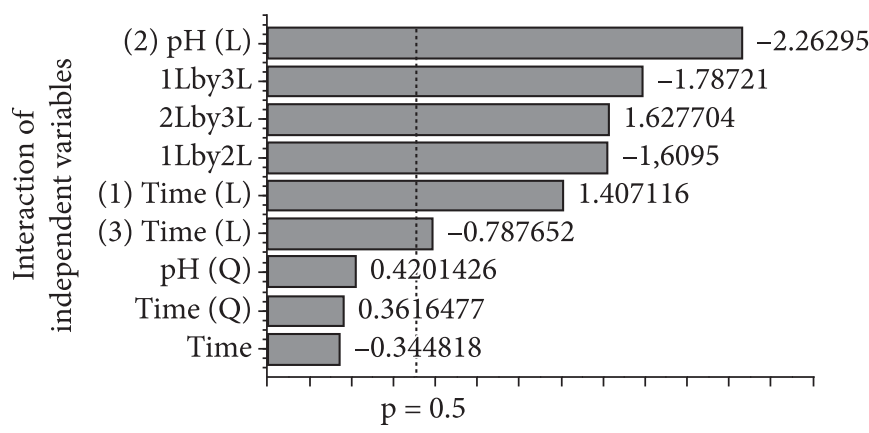

Standardized effect estimate (absolute value)

Figure 3. Pareto graphic showing the significant influence $(\mathrm{p}=0.5)$ of the interaction between time, temperature, and $\mathrm{pH}$ on aflatoxin $\mathrm{B} 1$ production by isolate A21 in the CYA medium, where 1 represents the temperature, 2 represents the $\mathrm{pH}$, and 3 represents the incubation time. 
Table 2. Aflatoxin-producing ability: Analysis of non-aflatoxigenic isolates under different conditions.

\begin{tabular}{cccccc}
\hline Condition tested & Medium & $\mathrm{pH}$ & ${ }^{\circ} \mathrm{C}$ & Time (days) & Isolates produced \\
\hline A & YES & 5,2 & 25 & 11 & 2 \\
B & YES & 5,2 & 25 & 18 & $2 \mathrm{e} \mathrm{6}$ \\
C & YES & 4,0 & 20 & 14 & $1,3,4,5,7,9,12$ \\
D & CYA & 5,2 & 25 & 11 & - \\
E & CYA & 5,2 & 25 & 18 & 2 e 6 \\
F & CYA & 4,0 & 20 & 14 & $1,3,4,8,10,11$ \\
\hline
\end{tabular}

medium for the biosynthesis of aflatoxin $B_{1}$, which proved easy to prepare and relatively cheap.

Ordaz et al. (2003) used new media (CYA and YES + $0.6 \%$ of YCSD) to detect aflatoxigenic potential and verified that all isolates, initially toxigenic, produced a fluorescent ring under UV light. Twenty-eight non-aflatoxigenic isolates were subsequently tested on these media and none presented the fluorescent ring. The analyses of aflatoxins by HPLC were also negative.

Different strains of $A$. flavus may produce aflatoxins in different proportions when cultivated under similar conditions (HUSSEIN; BRASEL, 2001). According to Vaamonde et al. (2003), data from different geographic areas show the largest potential variation in mycotoxin-producing Aspergillus.

The isolates that were initially thought to be nonaflatoxigenic but proved to be producers under the conditions and media tested in this study were tested again on coconut agar. Eight isolates still showed negative results on this medium. These data are similar to those reported by Taniwaki (1996) who described coconut agar (LIN; DIANESE, 1976) as unreliable for the detection of the toxigenic potential of A. flavus and A. parasiticus aflatoxin due to false negative results.

\section{Conclusions}

Isolate $\mathrm{A} 43$ produced aflatoxin $\mathrm{B}_{1}$ in a large variety of conditions and also produced the highest concentration of aflatoxin $B_{1}$ determined by the quantitative tests (206.4 ng.CFU ${ }^{-1}$ ). The thin layer method proved to be very efficient in detecting aflatoxin $\mathrm{B}_{1}$ generating highly satisfactory results in the quantitative analysis utilizing TLC with Photometric Measurements. The detection of the toxigenic potential of isolates of A. flavus on coconut agar is not efficient since some toxin-producing strains were not identified. As an alternative, the results of the present study suggest the use of the YES medium at $25^{\circ} \mathrm{C}$, at a $\mathrm{pH}$ of 5.2, and with an incubation time of 11 days to detect the toxigenic potential of A. flavus.

\section{References}

ABRANSON, D.; CLEAR, R. M. A convenient method for assessing mycotoxin production in cultures of Aspergilli and Penicillia. Journal of Food Protection, v. 59, p.142-144, 1996.

BELLÍ, N. et al. Influence of water activity and temperature on growth of isolates of Aspergillus section Nigri obtained from grapes. International Journal of Food Microbiology, v. 96, p. 19-27, 2004. PMid:15358502. http://dx.doi.org/10.1016/j. ijfoodmicro.2004.03.004

BRAGULAT, M. R. et al. Na easy screening method for fungi producing ochratoxin A in purê culture. International Food of Journal Microbiology, v. 71, p. 139-144, 2001. http://dx.doi.org/10.1016/ S0168-1605(01)00581-5

BRASIL, 2005. Physical-Chemical Methods for Analysis of Food. 4 Edn., Instituto Adolfo Lutz, Brasília. Capobiango.

BRESLER,G. et al. Mycotoxin-production potential of fungi isolated from amaranth seeds in Argentina. International Journal of Food Microbiology, v. 25, p. 101-108, 1995. http://dx.doi. org/10.1016/0168-1605(94)00117-O

D’MELLO, J. P. F; MACDONALD, A. M. C. Mycotoxins. Animal Feed Science Technology, v. 69, p. 155-166, 2002. http://dx.doi. org/10.1016/S0377-8401(97)81630-6

FILTENBORG, O. et al. Simple screning method for producing intracelluar mycotoxins in pure cultures. Applied and Environmental Microbiology, p. 581-585, 1983. PMid:6338829. PMCid:242327.

FILTENBORG, O. et al. Moulds and food spoilage. International Journal of Food Microbiology, v. 33, p. 85-102, 1996. http://dx.doi. org/10.1016/0168-1605(96)01153-1

FRISVAD, J. C.; FILTENBORG, O. Classification of Terverticillate Penicillia based on profiles of mycotoxin and other secundary metabolites. Applied and Environmental Microbiology, p. 1301-1310, 1983. PMid:6660869. PMCid:239568.

FRISVAD, J. C. et al. Secondary metabolite profiling, growth profiles and other tools for species recognition and important Aspergillus mycotoxins. Studies in Mycology, v. 59, n. 1, p. 31-37, 2007. PMid:18490955. PMCid:2275202. http://dx.doi.org/10.3114/ sim.2007.59.04

GIRAY, B. et al. Aflatoxin leavels in wheat samples consumed in some regions of Turkey. Food Control, v. 18, p. 23-29, 2007. http://dx.doi. org/10.1016/j.foodcont.2005.08.002

GUITAKOU, S. et al. Study of aflatoxin B1 and ochratoxin A production by natural microflora and Aspergillus parasiticus in black and green olives of Greek origin. Food Microbiology, v. 23, p. 612-621, 2006. http://dx.doi.org/10.1016/j.fm.2005.12.008

GQALENI, N. et al. Co-production of aflatoxin and cyclopiazonic acid in isolates of Aspergillus flavus. Food Additives and Contaminants, v. 13, p. 677-685, 1996.

GQALENI, N. et al. Effects of temperature,water activity,and icubation time on production of aflatoxins and cyclopiazonic acid by an isolate of Aspergillus flavus in surface Agar cultute. Applied and Environmental Microbiology, v. 63, p. 1048-1053, 1997. PMid:16535539. PMCid:1389133.

HOELTZ, M. Estudo da Influência de Manejos Pós-Clolheita na Incidência de Fungos e Micotoxinas no Arroz (Oryza sativa L.). 
2005. 77 f. Dissertação (Mestrado em Microbiologia Agrícola e do Ambiente)-Universidade Federal do Rio Grande do Sul, Porto Alegre, 2005.

HUSSEIN, H. S.; BRASEL, J. M. Toxicity, metabolism, and impact of mycotoxin on humans and animals. Toxicology, v. 167, p. 101-134, 2001. http://dx.doi.org/10.1016/S0300-483X(01)00471-1

INTERNATIONAL AGENCY FOR RESEARCH ON CANCER - IARC. Some Naturally Occurring Substance: Food Items and Contituents, Heterocyclic Aromatic Animes and Mycotoxins. Lyon: OMS, 2002.

IQBAL, A. A. et al. Aflatoxin contents of stored and artificially inoculated cereals and nuts. Food Chemistry, p. 699-707, 2006.

KLICH, M. A.; PITT, J. I. A laboratory guide to the common Aspergillus species and their teleomorphs. North Ryde: Commonwealth scientific and industrial research organization, 1988.

LANCASTER, M. et al. Quantitative measurements on wetted thin layer chromatography plates using a charge coupled device camera. Journal of Chromatography A, v. 1090, n. 1-2, p. 165-171, 2005. http://dx.doi.org/10.1016/j.chroma.2005.06.068

LEONTOPOULOS, D. et al. Black olives as substrate for Aspergillus parasiticus growth and aflatoxin B1 production. Food Microbiology, v. 20, p. 119-126, 2003. http://dx.doi.org/10.1016/S07400020(02)00080-1

LIN, M. T.; DIANESE, J. C. A coconut-agar medium for rapid detction of aflatoxin produtiction by Aspergillus spp. Phytopathology, p. 14661469, 1976. http://dx.doi.org/10.1016/j.ijfoodmicro.2005.12.003

MEDINA, A. et al. Survey of the mycobiota of Spanish malting barley and evaluation of the mycotoxin producing potential of species of Alternaria, Aspergillus and Fusarium. International Journal Food Microbiology, v. 108, p. 196-203, 2006. http://dx.doi.org/10.1016/j. ijfoodmicro.2005.12.003

MOLINA, M.; GIAMUZZI, L. Modelling of aflatoxin production by Aspergillus parasiticus in a solid medium at different temperatures, $\mathrm{pH}$ and propionic acid concentrations. Food Research International, v. 35, p. 585-594, 2002. http://dx.doi.org/10.1016/ S0963-9969(01)00161-2

MOSS, M. Mycotoxin review- Aspergillus e Penicillium. Mycologist, v. 16, n. 3, 2002. http://dx.doi.org/10.1017/S0269915X02003014
ORDAZ, J.J. et al. Development of method for direct visual determination of aflatoxin production by colonies of the Aspergillus flavus group. International Journal of Food Microbiology, v. 83, p. 219-225, 2003. http://dx.doi.org/10.1016/S0168-1605(02)00362-8

PARK , K. Y.; BULLERMAN, L. B. Effect of cycling temperatures on aflatoxin production by Aspergillus parasiticus and Aspergillus flavus in rice and cheddar cheese. Journal of Food Science, v. 48, p. 889-896, 1983. http://dx.doi.org/10.1111/j.1365-2621.1983. tb14924.x

PITT, J. I., HOCKING, A.; GLENN, D. R. Na improved medium for the detection of Aspergillus flavus and Aspergillus parasiticus. Journal of Applied Bacteriology, v. 54, p. 109-114, 1983.

PRZYBYLSKI, W. Formation of aflatoxin derivates on thim layer chromatographic plates. Journal of the Association of Oficcial Analytical Chemists, v. 58, n. 1, p. 163-164, 1975.

RODRIGUES, M. I. Planejamento de Experimentos e otimização de processos: uma estrategia sequencial de planejamentos. Campinas: Casa do Pão Editora, 2005.

SALEEMULLAH, A. I. et al. Aflatoxin contents of stored and artificially inoculated cereals and nuts. Food Chemistry, v. 98, p. 699-703, 2006. http://dx.doi.org/10.1016/j.foodchem.2005.06.034

SMEDSGAARD, J. Micro-scale extraction procedure for standardized screening of fungal metabolite production in cultures. Journal Of Chromatografy, v. 706, p. 264-270, 1997. http://dx.doi.org/10.1016/ S0021-9673(96)00803-5

SWEENEY, J.; DOBSON, A. D. W. Mycotoxin production by Aspergillus, Fusarium and Penicillium species. International Journal of Food Microbiology, v. 43, p. 141-158, 1998. http:// dx.doi.org/10.1016/S0168-1605(98)00112-3

TANIWAKI, M. H. Meios de cultura para contagem de fungos em alimentos. Boletin SBCTA, v. 30, n. 2, p. 132-141, 1996.

VAAMONDE, G. et al. Variability of aflatoxin and cyclopiazonic acid production by Aspergillus section flavi from different substrates in Argentina. International Journal of Food Microbiology, v. 88, p. 79-84, 2003. http://dx.doi.org/10.1016/S0168-1605(03)00101-6

WEELER, K. A. et al. Influence of $\mathrm{pH}$ on the growth of some toxigenic species of Aspergillus, Peniccillium and Fusarium. International Journal of Food Microboilogy, v. 12, p. 141-150, 1991. http:// dx.doi.org/10.1016/0168-1605(91)90063-U 